\title{
Variability of water intake in settlement units adjacent to Wrocław
}

\author{
Wojciech Cieżak ${ }^{1, *}$, and Jan Cieżak ${ }^{1}$ \\ ${ }^{1}$ Wrocław University of Science and Technology, Faculty of Environmental Engineering, Department of Water Supply \\ and Sewerage, ul. Wybrzeże Wyspiańskiego 27, 50-370 Wrocław, Poland
}

\begin{abstract}
Water intake in rural settlements adjoining large cities is variable and depends on many factors. In these places increasingly often a change in the character of water use from rural to the one typical of urban housing estates is observed. This is due to the expansion of housing, especially single-family housing, and migration of people from large cities. As a consequence, the standard of home furnishings improves and water is used not only for domestic purposes, but also for watering gardens and greenery, the filling and operation of swimming pools, etc. Considering the above, the authors present the results of own research relating to the analysis of water intake in villages adjacent to Wrocław.
\end{abstract}

\section{Introduction}

The size and distribution of consumer demand for water in the area of a given administrative unit is the basis for dimensioning its water supply and sewerage facilities. It is also a major element in the mathematical modelling of water or sewage flows [1-3].

The estimation of the demand for water on the basis of water distributions is an essential part of planning and designing the development and operation of water supply systems. It is important to determine the consumers' water needs in order to correctly distribute them over the considered area [4-6]. Depending on the aim of the particular study (a general plan, development programming, technical-economic assumptions for water mains construction or extension), a different degree of precision of predicting the future water needs is required. Most often the following three methods are used:

- a method based on global indices of the demand for water for domestic-municipal and production purposes per 1 inhabitant, which is used in general feasibility and conceptual studies. The method uses unit water demand indices which take into account the total water needs per 1 inhabitant. The global indices are determined on the basis of analytical-statistical studies of the water consumption so far, its multi-annual trends and the predicted trends stemming from the country's long-term and targeted socio-economic development assumptions; - a method based on aggregate indices of water demand for different consumers in a settlement unit area per 1 inhabitant, which can be used in general plans and in technical-economic assumptions for water mains construction and extension for settlement units having a multifunctional character. In this case, the total daily water demand is the sum of the partial needs determined for the different groups of consumers on the basis of the unit aggregated indices and the assumptions concerning the long-term living conditions of the population;

- a method of water demand balancing for different purposes in a settlement unit area, using detailed unit water demand indices. This is the most labour-intensive method, but enabling one to determine the water abstractions more precisely. The balance is drafted on the basis of the development plan's descriptive part and drawings and the detailed water demand indices determined for the particular consumers and the different purposes. The average and maximum daily water demand determined using this method is the sum of the partial demands of the particular categories of consumers.

The method based on aggregate indices and the one based on detailed unit water demand indices are most often used for balancing the current and long-term water needs. The indices and also daily water demand irregularity coefficients are assumed in accordance with the relevant legal acts and the literature on the subject. From among the current legal acts one should mention here the Minister of Infrastructure Order of 14 January 2002 concerning the determination of average water consumption standards, which can serve as the legal basis for drawing a balance of water needs, even though the Order concerns the determination of average water consumption standards for individual water customers in the case when there is no main water meter. The previously issued guidelines for balancing water needs, such as: Technical guidelines for designing the size of a municipal main with regard to water demand; the Order of the Municipal Economy Minister (Bldg. Gaz. No. 16, it. 68, 9.12.1966); Directives for programming water demand and sewage amount in urban settlement units,

Corresponding author: wojciech.ciezak@pwr.edu.pl 
Ministry of Administration, Local Economy and Environmental Protection, 1978; and Directives for programming water demand and sewage amount in urban settlement units, Institute for Spatial and Municipal Economy, 1991; became invalid because of the marked decline in water consumption in the 1990s and the change from the upward trend to a downward trend.

The quoted above Order of 2002 includes average water consumption standards for households, watering home gardens and agricultural crops, services, farms and livestock facilities, servicing motor vehicles, agricultural machinery and workshops, agricultural products and food processing plants, construction works, chemical plant protection and military facilities belonging to the Defence Department and the Ministry of the Interior. However, to this day the directives have not been brought up to date by government institutions.

According to the Order of 2002, the flow of water consumed by households having only a kitchen sink and a toilet (no bathroom and no hot water) amounts to 70-90 liters per capita per day (lpcd) while in the case of households additionally having a bathroom with a local source of hot water, it amounts to as much as $80-100$ lpcd. In Poland, households of this type occur mainly in rural areas. The above flow rates are similar to the ones observed over the last decade in rural areas in Poland (Fig. 1 and Fig. 2) [7].

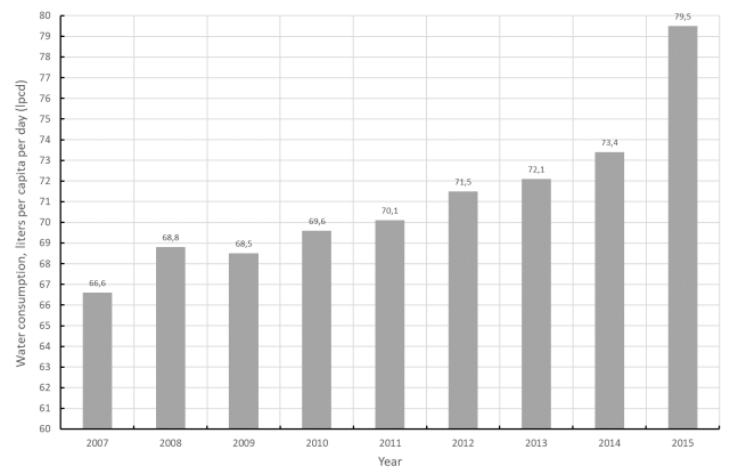

Fig. 1. Consumption of mains water by households in rural areas in the years 2007-2015 [7].

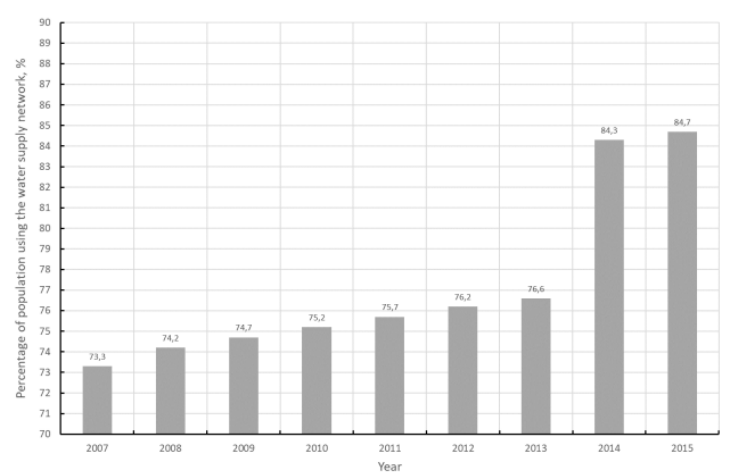

Fig. 2. Percentage of population using the water supply network in rural areas in 2007-2015 [7].

The Order also includes average water consumption standards for, among other things, watering home gardens (including crops, lawns and greenery) -
$2.5 \mathrm{~L} / \mathrm{m}^{2}$ per day, and, to a quite a large extent, average water consumption rates for services, livestock facilities and agricultural product and food processing plants.

In the literature on the subject there is relatively little information about water consumption trends in rural settlements, especially the ones adjoining large cities. Since the character of such developments has been changing from rural to the one typical of urban housing estates, it is important to take this fact into account when calculating water needs. Ogiołda and Kozaczek [8] analysed water consumption in the rural water supply systems in the Głogów District. These are areas directly adjacent to Głogów and include the places: Borek, Bytnik, Przedmoście, Zabornia, Wilków, Klucze, Krzekotów and Serby Stare. The calculations and analysis of water consumption were made for data for the years 1995-2011. The mean value of the unit water demand index amounted to $82.2 \mathrm{lpcd}$ for the Borek water supply system and to $68.8 \mathrm{lpcd}$ for the Wilków water supply system while the daily water demand irregularity coefficient amounted to respectively 1.3 and 1.7. Pawełek et al. [9] describe the variation in water consumption in the rural households in 8 villages in the Brzesko District in the years 2000-2012. The analyses showed that the unit water consumption in the studied area ranged from 30.9 to $70.5 \mathrm{lpcd}$, on average amounting to 46.7 lpcd. Orzechowska [10] studied 16 rural group water mains in the Podlasie province in the years 2006-2010. The author showed that the average water consumption in the analysed area amounted to 86.0 lpcd.

Trade journals most often publish the average unit water demand for water in single-family housing in urban areas [11-13]. The demand usually ranges from 90.0 to 180.0 lpcd. Daily water consumption irregularity coefficients $\left(N_{d}\right)$, expressing the variability of water abstraction by water consumers, are reported much less frequently. According the directives $(1978,1991)$, the values of $N_{d}$ for single-family housing are assumed in the rage of 1.5-2.0.

\section{Description of the area covered by the study}

An analysis of water needs was carried out for the following three districts in the Wrocław agglomeration: Oborniki Śląskie (the southern part of the District) - data for 2008, Wisznia Mała - data for 2007 and 2010 and Czernica - data for 2015. The districts are directly adjacent to Wrocław (Fig. 3).

In the Oborniki Śląskie District, places located in its southern part were analysed. This area is supplied with water by the Lubnów water supply system which covers the places: Lubnów, Niziny, Uraz, Raków, Kotowice, Paniowice, Zajączków and Pęgów, and by the Golędzinów water supply system supplying water to the places: Golędzinów and Nowosielce. In these water supply systems underground water is drawn from drilled wells and then it is treated and stored in clearwells. From the clearwells the water is pumped into the water-pipe network by water pumping stations. The network is built 
of PVC pipes 90-225 $\mathrm{mm}$ in diameter. In 2008 the considered area was inhabited by 4741 inhabitants. The water consumers are mainly single-family housing and services and to a small degree agriculture and industry.

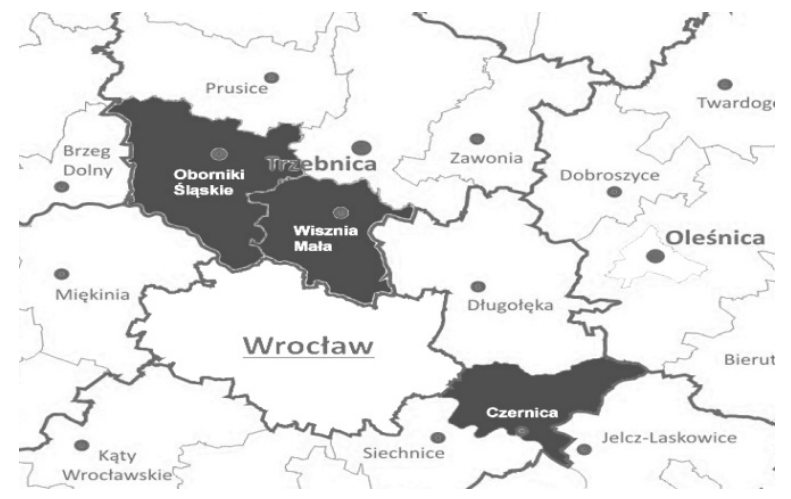

Fig. 3. Area covered by the study.

The analysis of water consumption in the Wisznia Mała District was carried out in two stages. In the first stage the structure of the water needs in the places: Psary, Szymanów and Krzyżanowice (the Psary water supply system) and Kryniczno and Rogoż (the Kryniczno water supply system) was studied. In both the water supply systems underground water is drawn, which is subsequently treated and stored in clearwells and then pumped into the water-pipe networks by pumping stations. The network is built of PVC pipes 90$225 \mathrm{~mm}$ in diameter. In 2007 the population in the considered area amounted to 2,732 inhabitants. In the second stage investigations were carried out in the northern part of the District in the places: Machnice, Wysoki Kościół, Piotrkowiczki and Mienice (a pumping main) and Wisznia Mała, Ligota Piękna Pierwoszów, Malin, Strzeszów, Ozorowice and Szewce (a gravity main). The water-pipe system is supplied with water from the underground water intake in Pierwoszów and Machnice. The water-pipe network is built of cast-iron and PVC pipes $90-300 \mathrm{~mm}$ in diameter. In 2010 the places mentioned above were inhabited by 5,578 persons. The major water consumers in the whole analysed area are single-family housing and services. Water used for agricultural and industrial purposes amounted to a small percentage.

In 2015 studies were carried out in the Czernica District. The structure of water needs was determined for all the places located in the District, i.e. Nadolice Wielkie, Chrząstawa Mała, Chrząstawa Wielka, Nadolice Małe, Krzyków, Dobrzykowice, Kamieniec Wrocławski, Łany, Gajków, Jeszkowice, Czernica, Wojnowice and Ratowice. The particular places are supplied with water from the group water main with a water treatment plant in Nadolice Wielkie and from the Wrocław main. The water-pipe network is built of PVC and PE pipes $90-225 \mathrm{~mm}$ in diameter. The major water consumers are single-family housing and services, and industrial plants. Agriculture is a minor water consumer.
In 2015 the population of the District amounted to 12,824 inhabitants.

In the studied areas the water supply network covers all the water consumers.

\section{Research results}

The results of the research into the water needs in the Oborniki Śląskie District, the Wisznia Mała District and the Czernica District are presented in Table 1 and illustrated in Fig. 4. The analyses were based on the data collected in the district organizational units administering the water supply systems described above.

Table 1. Summary of research results.

\begin{tabular}{|c|c|c|c|c|c|}
\hline \multirow{2}{*}{ Place name } & \multirow{2}{*}{$\begin{array}{l}\text { Popu- } \\
\text { lation }\end{array}$} & \multicolumn{2}{|c|}{$\begin{array}{l}\text { Water demand, } \\
\mathrm{m}^{3} / \mathrm{d}\end{array}$} & \multirow{2}{*}{$\begin{array}{l}\text { Average } \\
\text { water } \\
\text { consum- } \\
\text { ption per } \\
\text { inhabi- } \\
\text { tant, } q_{j} \\
\text { lpcd }\end{array}$} & \multirow{2}{*}{$\begin{array}{c}\text { Daily } \\
\text { water } \\
\text { demand } \\
\text { irregu- } \\
\text { larity } \\
\text { coeffi- } \\
\text { cient, } N_{d}\end{array}$} \\
\hline & & $\mathrm{Q}_{\mathrm{av} .}$ & $\mathrm{Q}_{\operatorname{maxd}}$ & & \\
\hline \multicolumn{6}{|c|}{ Oborniki Śląskie District } \\
\hline Golędzinów & 462 & 39.65 & 89.98 & 85.8 & 2.27 \\
\hline Kotowice & 380 & 43.11 & 96.19 & 113.4 & 2.23 \\
\hline Lubnów & 520 & 40.00 & 100.63 & 76.9 & 2.52 \\
\hline Niziny & 38 & 2.94 & 6.49 & 77.4 & 2.21 \\
\hline Nowosielce & 51 & 3.33 & 7.92 & 65.3 & 2.38 \\
\hline Paniowice & 307 & 28.43 & 71.27 & 92.6 & 2.51 \\
\hline Pęgów & 1680 & 163.70 & 335.06 & 97.4 & 2.05 \\
\hline Raków & 76 & 6.29 & 15.83 & 82.8 & 2.52 \\
\hline Uraz & 900 & 59.87 & 132.91 & 66.5 & 2.22 \\
\hline Zajączków & 327 & 23.05 & 55.21 & 70.5 & 2.40 \\
\hline TOTAL & 4,741 & 410.37 & 911.49 & 86.6 & 2.22 \\
\hline \multicolumn{6}{|c|}{ Wisznia Mała District } \\
\hline Psary & 1006 & 107.67 & 207.81 & 107.0 & 1.93 \\
\hline Szymanów & 728 & 80.27 & 159.39 & 110.3 & 1.99 \\
\hline Krzyżanowice & 405 & 41.37 & 82.72 & 102.1 & 2.00 \\
\hline Kryniczno & 362 & 58.36 & 155.97 & 161.2 & 2.67 \\
\hline Rogoż & 231 & 22.47 & 43.58 & 97.3 & 1.94 \\
\hline TOTAL & 2732 & 310.14 & 649.47 & 113.5 & 2.09 \\
\hline Ligota Piękna & 904 & 104.83 & 282.62 & 116.0 & 2.70 \\
\hline Machnice & 213 & 19.29 & 56.42 & 90.6 & 2.92 \\
\hline Malin & 512 & 58.47 & 172.12 & 114.2 & 2.94 \\
\hline Mienice & 265 & 28.12 & 85.20 & 106.1 & 3.03 \\
\hline Ozorowice & 380 & 35.01 & 92.33 & 92.1 & 2.64 \\
\hline Pierwoszów & 188 & 20.51 & 55.97 & 109.1 & 2.73 \\
\hline Piotrkowiczki & 349 & 44.83 & 139.81 & 128.5 & 3.12 \\
\hline Strzeszów & 1040 & 149.19 & 341.78 & 143.5 & 2.29 \\
\hline Szewce & 875 & 100.93 & 251.16 & 115.3 & 2.49 \\
\hline Wisznia Mała & 708 & 87.33 & 230.02 & 123.3 & 2.63 \\
\hline Wysoki Kościół & 144 & 14.12 & 44.31 & 98.1 & 3.14 \\
\hline TOTAL & 5,578 & 662.63 & $1,751.74$ & 118.8 & 2.64 \\
\hline \multicolumn{6}{|c|}{ Czernica District } \\
\hline Nadolice W. & 1204 & 201.81 & 428.71 & 167.6 & 2.12 \\
\hline Chrząstawa M. & 1028 & 121.17 & 247.39 & 117.9 & 2.04 \\
\hline Chrząstawa W. & 1063 & 135.82 & 280.57 & 127.8 & 2.07 \\
\hline Nadolice Małe & 246 & 36.11 & 76.67 & 146.8 & 2.12 \\
\hline Krzyków & 371 & 56.59 & 121.32 & 152.5 & 2.14 \\
\hline Dobrzykowice & 1477 & 289.71 & 633.14 & 196.1 & 2.19 \\
\hline Kamieniec Wr. & 2336 & 330.21 & 680.36 & 141.4 & 2.06 \\
\hline Lany & 181 & 27.41 & 49.80 & 151.4 & 1.82 \\
\hline Gajków & 1091 & 158.15 & 318.24 & 145.0 & 2.01 \\
\hline Jeszkowice & 910 & 108.93 & 219.03 & 119.7 & 2.01 \\
\hline Czernica & 1257 & 147.18 & 279.50 & 117.1 & 1.90 \\
\hline Wojnowice & 692 & 87.93 & 176.55 & 127.1 & 2.01 \\
\hline Ratowice & 968 & 85.86 & 169.41 & 88.7 & 1.97 \\
\hline TOTAL & 12,824 & $1,786.88$ & $3,680.69$ & 139.3 & 2.06 \\
\hline
\end{tabular}




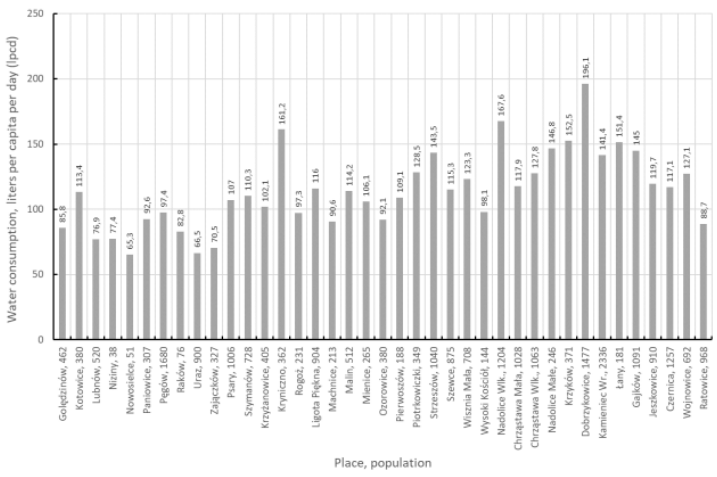

Fig. 4. Average unit water consumption in analysed places.

In the case of the parts of the Oborniki Śląskie District and the Wisznia Mała District, the collected data concerned the amount of water drawn for housing (households and watering home gardens), services, farms and livestock facilities, servicing motor vehicles and production plants. While in the Czernica District the average daily water consumption measured by water meters located at water service points was analysed with a special regard to the use of the drawn water.

The analyses show a wide variation of both the average unit water consumption, ranging from 65.3 to $196.1 \mathrm{lpcd}$, and the daily water demand irregularity coefficient, ranging from 1.82 to 3.14 .

As regards average unit water consumption, the results for the places in the Oborniki Sląskie District, directly adjacent to Wrocław, coincide with the values given in the Minister of Infrastructure Order of 14 January 2002, whereas the ones for the places in the Wisznia Mała District and the Czernica District, especially in Kryniczno $\left(q_{j}=161.2 \mathrm{lpcd}, N_{d}=2.67\right)$, Nadolice Wielkie $\left(q_{j}=167.6 \mathrm{lpcd}, N_{d}=2.12\right)$ and Dobrzykowice $\left(q_{j}=196.1 \mathrm{lpcd}, N_{d}=2.19\right)$, are higher than the values published in the Order and in the trade journals. Various factors contribute to the relatively large water intake in the considered places, particularly in the Czernica District. First of all one should note the change in the use of mains water from rural to the one typical of urban housing estates, at a considerable use of water for purposes other than domestic, including watering lawns and greenery and the operation of swimming pools. Also quite significant is water abstraction for construction purposes.

\section{Conclusions}

The structure of the water needs in the water supply systems of the Oborniki Śląskie District, the Wisznia Mała District and the Czernica District, directly adjacent to Wrocław has been studied over the last decade.

The analyses have shown that various factors have a bearing on water intake variability. The determined average water consumption per inhabitant ranges from 65.3 to 196.1 lpcd while the daily water consumption irregularity coefficient ranges from 1.82 to 3.14 . For most of the considered places, especially for the Czernica District, these values differ from the ones reported in the literature. It should be noted that this is due to the change in the character of the use of water by its consumers in the studied area from rural to the one typical of urban housing estates, with a considerable use of water for other than purely household purposes, such as watering lawns and greenery and the operation of swimming pools.

The observations indicate that it is necessary to continue the research on the variability of water consumption, particularly daily water consumption irregularity, in rural settlements adjacent to large cities in Poland.

This research was carried out as part of the statutory activity of the Faculty of Environmental Engineering at Wrocław University of Science and Technology, funded by the Ministry of Science and Higher Education in 2017 and 2018.

\section{References}

1. I. Zimoch, E. Łobos, Environ. Prot. Eng. 36, 4 (2010) http://epe.pwr.wroc.pl/2010/zimoch_4-2010.pdf

2. Z. Siwoń, W. Cieżak, Instal Spec. edit. (2008)

3. A. Kotowski, Foundations of the safe dimensioning of land drainages. Sewerage networks (Vol. I) (Seidel-Przywecki Publishing House, Warsaw, 2015)

4. Z. Siwoń, J. Łomotowski, W. Cieżak, P. Licznar, J. Cieżak, The analysis and prediction of water distribution in water supply systems (in Polish). Polish Academy of Sciences. Civil Engineering Committee. Institute of Fundamental Technological Research, Warsaw (2008)

5. I. Zimoch, E. Łobos, Environ. Prot. Eng. 38, 3 (2012)

http://epe.pwr.wroc.pl/2012/3-2012/Zimoch_3 2012.pdf

6. J.L. Wescoat Jr, S. Fletcher, M. Novellino, Water Policy 18, 4 (2016)

7. Municipal Infrastructure in 2014 and 2015 (in Polish). Central Statistical Office $(2015,2016)$

8. E. Ogiołda, M. Kozaczek, Sci. Papers of Zielona Góra University 152, (2013)

9. J. Pawełek, T. Bergel, O. Wojciechowska, Acta Sci. Pol. Formatio Circum. 14, 4 (2015)

10. M. Orzechowska, JEENG 26, (2011)

11. B. Tchórzewska-Cieślak, 12th All-Poland ScientificTechnical Conference, Issues of water supply and water disposal in agricultural-industrial regions $\mathbf{3 0}$, (2005)

12. J. Pawełek, G. Kaczor, Infrastrukt. Ekol. Ter. Wiejskich 2, (2006)

13. H. Hotloś, Ochr. Srod. 32, 3 (2010) 